\title{
Representation of Emotional Modality in the Materials of English, Russian and Tatar Media
}

\author{
I. G. Akhmetzyanov
}

Kazan Federal University, RUSSIA

sc 56518244400

N. K. Mullagaliev

Kazan Federal University, RUSSIA

(iD) 0000-0002-6353-3416

narkizmoullagaliev@mail.ru

\section{A. K. Garaeva}

Kazan Federal University, RUSSIA

sc 57201648864

\author{
ARTICLE INFO \\ Received: 19 July 2019 \\ Accepted: 7 October 2019 \\ Published: 10 November 2019 \\ DOI: https://doi.org/10.29333/ojcmt/6275 \\ ABSTRACT
}

The relevance of this research is closely bound with the general tendency of linguistics in the attempt to reveal the human factor in the language, as the most valuable results of the research are found in comparison of the languages. The goal of this article is to find out the common features and differences in covering the problems of refugees by the journalists in English, Russian and Tatar. The main approach of the research is interdisciplinary which requires the usage of such sciences as Sociology, Journalism and Linguistics. The article deals with the issue of objective (hidden) and subjective (open) emotional modality of the authors of the periodicals of three genetically unrelated languages. Authors consider metaphors as a way of expressing emotional modality and feelings towards the problem of refugees in the world.

Keywords: international relations, political linguistics, emotional modality, objective modality, subjective modality, metaphor

\section{INTRODUCTION}

The Importance of the Problem

In the modern world, periodicals (newspapers, magazines) are an integral part in human life. The media covers the rapidly changing situation in the region, in the country, in the world. In the age of information technology, society needs to receive information quickly and efficiently. In this connection, the editors of the media print their materials not only on paper, but also in the Internet space, which allows them to spread the news not only synchronously, but also diahronnously. According to Dobrosklonskaya (2005, p. 3), media texts in English take a special place in the global information flow.

\section{Status of a Problem}

Linguists all over the world pay special attention to the lexical parameters of media texts, since they "are integral components of the social being of a modern person, the main 
means of his exposure to the world events, mediators in the formation of culture" (Volodina, 2008, p. 3).

The language of the media is a discourse aimed at "promoting certain ideas, the emotional impact on the citizens of the country and encouraging them to take political actions, develop social consensus, make and substantiate social and political decisions in the multiplicity of points of view in the society (Chudinov, 2001, p. 36).

The relevance of this research is closely bound with the general tendency of linguistics in the attempt to reveal the human factor in the language, as the most valuable results of the research are found in comparison of the languages.

\section{The Research Hypothesis}

This article considers the emotional modality as a means of expressing author's positions in covering the problems of refugees in the Russian-speaking, English-speaking and Tatar-speaking media.

Linguistic ways of expressing opinions and assessments are highly diverse, ranging from direct explicit to hidden implicit. They include a wide range of language tools, such as: negative or positive connotations; manipulation; stylistic techniques (Dobrosklonskaya, 2005, p. 133-134).

\section{METHODOLOGICAL FRAMEWORK}

The article deals with the issue of objective (hidden) and subjective (open) emotional modality of the authors of the periodicals of three genetically unrelated languages. Authors consider metaphors as a way of expressing emotional modality and feelings towards the problem of refugees in the world.

\section{DISCUSSIONS AND RESULTS}

Emotional modality in periodical materials can be both objective and subjective, both hidden and open, both positive and negative. Objective modality expresses different kinds of attitude of affirmation to the reality.

Let us give the examples from the English-language press. For example, the BBC journalist Rick Kelsey in an article entitled "Asylum seekers, migrants or refugees: Which word is correct?" dated January 11, 2019 writes:

"Charlotte does have concerns about words used around migration such as "wave, flow, flooded by".

She believes this type of language can mean people in a country where migrants are regularly arriving can see them as "products not people".

Then Prime Minister David Cameron was criticised in 2015 for talking about "a swarm of people coming across the Mediterranean, seeking a better life, wanting to come to Britain” (https://www.bbc.com).

Or «The telegraph» journalist Raf Sanchez in the article «Erdogan warns attack on Idlib will send Syrian refugees heading to Europe» dated September 11, 2018 writes:

"The Turkish leader has been mounting a public campaign to focus the world's attention on the dangers of an attack on the rebel-held province, where around three million people are bracing themselves for an assault by Bashar al-Assad's forces". 
Considering the examples taken from the English-language newspapers, it can be assumed that the objective modality is expressed through the transfer of attitudes towards the reality of other persons (the majority).

As in the English-language news texts, the authors of Russian-language texts convey an objective modality through attitudes towards the reality of certain characters, for example, a refugee Silvia, nameless politicians, Emilio volunteer, Deutsche Welle news agency, a representative of the civil guard.

In the Tatar-language periodical press, an example of an objective modality can be found in an article on the "tatar-today" portal. Rashit Fathrahmanov in his article "Evropada korban chaluny gaeplilər, ə M'yanmada menləgən moselmannyn haiwan kebek sueluyn kurmilər (The slaughter of animals as a sacrifice is blamed in Europe, but the slaughter of millions of Muslims in Myanmar is not noted)" dated by September 2017 writes:

"Rossiyanen moselman aktivistlary, aerym alganda, advokat Morad Musaev, M'yanmaga baryp kimsetelgan halyknyఘ halen jinelaiterga, anyn problemalaryn kin jamagat'chelekka jitkererga omtyldy".

(Russian Muslim activists, namely the lawyer Morad Musaev, went to Myanmar to help people, to demonstrate their problem to the world).

In terms of the expressing objective modality, Tatar authors of news texts use the same methods as the English and Russian journalists. The journalist Rashit Fathrahmanov expresses objective modality through the words of the lawyer Morad Musaev and Reuter media agency. In this aspect, we see similarities in the journalism of various countries.

If we take into account the fact that objective modality is represented by different types of relations to reality, while it can still be described as a hidden modality, the subjective modality conveys different kinds of visions of the speaker to the stated material.

Emotions, representing the sensual form of cognition as a direct reaction to an external or internal stimulus based on the satisfaction of a person's need, as opposed to modality, are not a factor constituting and determining the character of judgment in logic (Mullagaliev, 2016, p. 16). All these means of emotional expression can be classified according to their nature and interpreted in terms of absolute evaluative predicates "good I bad", henceforth it is logical to assume that emotionality, being naturally anthropocentric, must be in contact with evaluations that are unthinkable outside the subject of the evaluation (Romanova, 2008, p. 20).

The subjective modality can be considered as an open modality, as represented by the following examples from the periodical press.

Moulid Hujale, "The guardian» journalist, in the article dated January 9, 2019 «Despair endangers Dadaab refugees as smugglers seize their moment» writes:

"Since 2014, about 80,000 have returned to Somalia through a voluntary repatriation programme, sponsored by the UN refugee agency. The security situation in Somalia remains dire, with deadly attacks taking place in the capital almost every week. In early November, multiple bomb blasts killed 52 people and injured more than 100 others" (https://www.theguardian.com).

Based on the above examples, it can be assumed that in the English-language press the subjective modality is expressed less frankly and openly, but more restrained. This happens, perhaps, due to a number of reasons related, firstly, to the mentality of the English people, who, if they disagree with something, can murmur, or apologize a 
thousand times for their statements, rather than publicly say everything about what they think; secondly, with the policies pursued by Western European states in dealing with the flow of refugees. Unlike English-speaking journalists, Russian authors are not constrained in their statements noted in the following examples.

As it can be noted from the examples of Russian-language texts, the authors use vivid language expressing a subjective or open modality. In Tatar-language articles, as well as in Russian-language news stories, the authors more openly express their point of view on a particular event.

For example, the journalist of the newspaper "Shahri Kazan" in the article "Ukraina kachaklary: «Bez kүrgənnərne sez aңlamayachaksyz» (Ukranian refugees: "You will never understand what we have seen")" writes:

"Kachaklarny bugenge konda in kurkytkany - bilgesezlek. Tulaj toraktagylary avgust ahyrynda bezne kaya kuyarlar dip kajgyrsalar, kuplaren eshsezlek mas’alase borchyj. Sugysh echenda kalgan, kajsy kaya taralyshkan tugannaryn, yakynnaryn ujlap ozgalanalar alar. Kazanga kildelar da, alarga bar yaklap kader-hormat kyrsatela, ber kajgylary da kalmagan dip ujlauchylar isa tiran yalgyshalar».

(Refugees are scared of uncertainty. Those who live in the dormitory are worried about their future in August, whereas the others are concerned about unemployment. They are also disturbed by the fate of their relatives who were scattered during the war. If someone thinks that they come to Kazan and are given everything are wrong). (http://shahrikazan.ru).

From the above examples of periodicals, it can be concluded that while expressing an objective modality, there is almost no difference in all these languages, they all convey a veiled vision to reality on behalf of the majority, which can also be considered a hidden modality. When expressing the subjective modality, there can be noted some differences in the English-speaking and Russian-language materials, as well as in Tatar-speaking texts, where, firstly, the mentality of various peoples is reflected, and secondly, the policy of the states towards refugees. If the British are restrained in their emotions, then Russian journalists use all the available emotional colors. As for the Tatar journalists, perhaps because of political or religious considerations, and, perhaps, out of upbringing, if they convey their emotions openly, it is not as eloquent as in Russian-language materials.

For an information-analytical text, the concept of evaluation in its politico-ideological refraction is fundamental, pivotal. Reflecting the ideological nature of the text, the category of ideological modality is implemented in a number of linguistic techniques aimed at expressing appreciation and opinion (Dobrosklonskaya, 2005, p. 133).

In addition to the lexical set in the transfer of emotional modality, the stylistic means of language are also actively involved, in our case, we will focus on the metaphors that journalists are willingly using when covering the problems of refugees.

Being a mirror of national cultural consciousness, metaphors can concisely and accurately convey the generally accepted ideas about a particular phenomenon; transform ideas into human representation. According to the semantics of metaphors, one can study the socio-economic and political history of a country, and the prevalence of certain metaphorical models - to give an idea of the situation in which it turned out (Vinogradov, 1994, p. 71).

In this case, the human factor appears as the central core. First, it is the author himself, who incorporates various ideas into metaphors and with their help, creates an 
image of reality. Secondly, it is the reader, who perceives these metaphors and makes up his own vision of reality. As noted by T.V. Romanova, the modern metaphor of newspaper materials, not only conveys information, but also has an emotional impact, transforming the linguistic worldview existing in the mind of the reader (Romanova, 2008, p. 79).

Let us give examples of the use of metaphorical units in the English-language press.

"It is a desperate, dangerous journey for refugees, but a lucrative business for people smugglers" (Despair endangers Dadaab refugees as smugglers seize their moment by Moulid Hujale 9 Jan 2019 https://www.theguardian.com).

\section{"The plan had faced an avalanche of international criticism.}

The Rohingya: stateless, helpless and at the mercy of cold politics" (What awaits any Rohingya refugees who return to Myanmar? By Nick Beake BBC News, Myanmar 28 December 2018 https://www.bbc.com).

English-speaking examples of the metaphor that authors used in their materials about refugees allowed to reveal only a small scale of the problem, but, in most cases, the sparked, extraordinarily emotional modality is demonstrated: desperate, dangerous journey; been shoehorned in a longside; what is expected to be a bloodbath; at the mercy of cold politics; an avalanche of international criticism. However, in the English press, you can also come across with an open, explicit expression of emotional modality, for example: outbreaks of violence; flee the Burmese military's brutal clearance operation; poisonous anti-Rohingya narrative.

If we turn to the examples of metaphorical units in the expression of the author's modality in Russian-language printed publications, here we can trace not only the explicit and implicit emotional modality, but also the expression of the author's emotions to the problem of refugees. Here are some examples:

"Stupaya myagko, slovno koty, podhodyat nigerijcy $i$ shepchut na uho. Immigranty iz Bangladesh nazojlivo vparivayut kitajskie suveniry, a eritrejskie zhenshchiny $v$ pokryvalah, usevshis' pryamo na trotuar, na lomanom ital'yanskom yazyke prosyat podayanie.

V nos b'yot sil'nyj zapah tualeta, vsyudu valyayutsya kuchi musora $i$ pishchevyh othodov.

Deportaciya odnogo nelegala obhoditsya $v 3000$ evro, $i$, esli narushitelej hvatat' pachkami, byudzhet goroda vyletit v trubu.

Tem ne menee desyatki tysyach bezhencev plyvut syuda s poberezh'ya razodrannoj grazhdanskoj vojnoj Livii, posle sverzheniya Kaddafi stavshej perevalochnym punktom dlya torgovcev lyud'mi».

(Stepping gently like cats, Nigerians come up and whisper in the ear. Immigrants from Bangladesh are pushing Chinese souvenirs on their way, and Eritrean women in bedspreads, sitting right on the sidewalk, beg in broken Italian.

There is a strong smell of toilet in the nose, piles of garbage and food waste are everywhere.

Deportation of one illegal man costs 3,000 euros, and, if there are enough violators in batches, the city's budget will fly into the pipeline.

Nevertheless, tens of thousands of refugees float here from the coast of Libya torn by civil war, which, after the overthrow of Gaddafi, has become a transit point for traffickers (http://www.aif.ru). 
In Russian-speaking examples, a wide range of authors' feelings is presented, which are conveyed with metaphors. For example, a feeling of irritation expressed by metaphoric units - "borodatye mal'chiki (bearded boys)"; "nazojlivo vparivayut kitajskie suveniry (Chinese souvenirs are pushed)"; "byudzhet goroda vyletit v trubu (The city budget will fly into the pipe)" and others." Journalists used the following metaphors to describe their feelings of anxiety: "stupaya myagko, slovno koty, podhodyat nigerijcy (Nigerians are walking softly like cats)"; "antimigrantskie nastroeniya v strane nakaleny do predela (Anti-migrant sentiments in the country are tensed to the limit) and others." Sympathy or indignation of the authors of articles on refugee issues is expressed in the following metaphors of "lyudej nabivayut $\mathrm{v}$ pomeshcheniya, slovno makarony $\mathrm{v}$ pachku (people are stuffed into the room like pasta in a pack)" and others.

As in the Russian-language periodicals, in the Tatar-language articles covering the refugee problem, both explicit and implicit emotional modalities are represented. Here are some examples:

"Tik inde ertkychlyk kyreneshlare kyrmameshka salyshudan uzgan ide" (But the atrocities were impossible not to be seen).

Keshelek den'yasy sоңgy kөnnarda tarih bitlarenə tagyn ber zur kanly tamga syzyp kujdy" (The mankind for the past few days draw one big bloody line on the pages of History).

In Tatar-examples above, in addition to feelings of irritation ("kyrməmeshkə salyshudan uzgan ide (it's already late not to see)", anxiety ("zur kanly Tamgha syzyp kuydy (draw big bloody line)"), sympathy or anger ("sugyshnyn жile (wind of war)", "cheterekle həldə (sensitive situation)"; you can also find criticism of policy and politicians in relation to the countries in which Muslims live, or countries where Muslims are under permanent threat of existence. For example, the metaphorical units "Myanmar itturagychy (Myanmar mincer)", "səyasətnen ere kalibrly tuplaryn hərəkətkə kiterde (forced the huge political canon to become active)" convey the author's emotions and criticism regarding the inaction of Western countries.

\section{CONCLUSION}

A comparative study of the expression of the emotional modality of the author's positions on the problem of refugees at the cognitive-culturological level allows us to identify similarities and differences in the migration discourses of the media and opens up new perspectives for studying lexical features in political media discourse.

\section{RECOMMENDATIONS}

The materials of this article can be recommended for use in modern practice of higher institutions as well as in the system of training journalists and linguists.

\section{ACKNOWLEDGEMENTS}

The work is performed according to the Russian Government Program of Competitive Growth of Kazan Federal University. 


\section{REFERENCES}

Bybee, J. L., Perkins, R. D., \& Pagliuca, W. (1994). The evolution of grammar: Tense, Aspect, and Modality in the languages of the world. Chicago: University of Chicago Press.

Chudinov, A. P. (2001). Rossiya v metaforicheskom zerkale: Kognitivnoe issledovanie politicheskoj metafory [Russia in a metaphoric mirror: cognitive investigation into politic metaphors]. Ekaterinburg: Ural. gos. ped. un-t.

Collins, P. (2009). Modals and Quasimodals in English. Amsterdam: Rodopi. https://doi.org/10.1163/9789042029095

Dobrosklonskaya, T. G. (2005). Voprosy izucheniya mediatekstov (opyt issledovaniya sovremennoj anglijskoj mediarechi) [Questions of investigating media texts (the experience of studying modern English media)]. Izd. 2-e, stereotipnoe. Editorial URSS.

Fachinetti, R., Palmer, F., \& Krug, M. (2006). Modality in Contemporary English. W. Frawley, E. Eschenroeder, S. Mills, Th. Nguyen. Berlin : Walter de Gruyter.

Mullagaliev N. K. (2016). Modal'nost' hudozhestvennogo teksta: (na materiale anglijskogo $i$ tatarskogo yazykov). [Fiction modality: based on the English and Tatar languages]. Kazan.

Palmer F. R. (1979). Modality and the English Modals. London, New York: Longman.

Romanova, T. V. (2008). Modal'nost'. Ocenka. Emocional'nost'. [Modality. Evaluating. Emotionality]. Nizhnij Novgorod: NGLU im. N.A. Dobrolyubova.

Vinogradov, S. I. (1994). Vyrazitel'nye sredstva v parlamentskoj rechi [Tekst]. Kul'tura parlamentskoj rechi. Nauka, 66-77.

Volodina, M. N. (2008). Yazyk SMI - osnovnoe sredstvo vozdejstviya na massovoe soznanie [Mass media language as the basic tool of mass manipulation]. YAzyk sredstv massovoj informacii: ucheb. posobie dlya vuzov. pod red. M.N. Volodinoj. Akademicheskij Proekt; Al'ma Mater, 6-24.

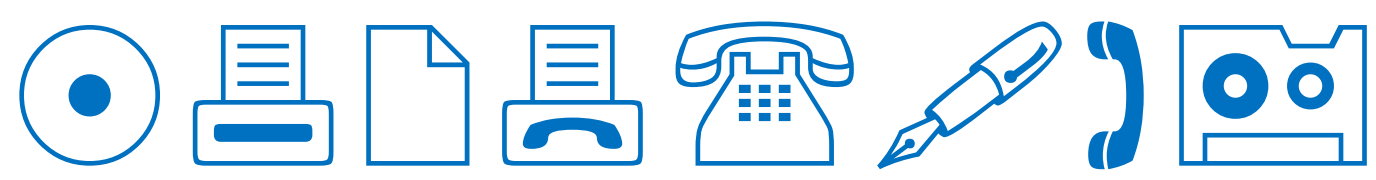

